\title{
Candidates of Cullin-Ring Ligases for Amelioration of Stress Tolerance in Plants
}

\author{
Mazahar Moin ${ }^{1 *}$, Achala Bakshi ${ }^{1}$, Madhav MS ${ }^{1}$ and Kirti PB ${ }^{2}$ \\ ${ }^{1}$ Biotechnology Division, ICAR-Indian Institute of Rice Research, India \\ ${ }^{2}$ Department of Plant Sciences, University of Hyderabad, India
}

ISSN: 2637-7659

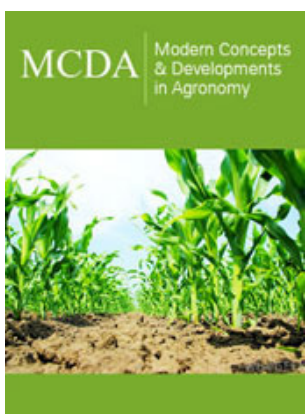

*Corresponding author: Mazahar Moin, DST-INSPIRE Faculty, ICAR-Indian Institute of Rice Research, Hyderabad, India

Submission: 眥 September 24, 2019

Published: 笽 November 7, 2019

Volume 5 - Issue 3

How to cite this article: Mazahar Moin, Achala Bakshi, Madhav MS, Kirti PB. Candidates of Cullin-Ring Ligases for Amelioration of Stress Tolerance in Plants. Mod Concep Dev Agrono.5(3). MCDA.000611.2019.

DOI: 10.31031/MCDA.2019.05.000611

Copyright@ Mazahar Moin, This article is distributed under the terms of the Creative Commons Attribution 4.0 International License, which permits unrestricted use and redistribution provided that the original author and source are credited.

\begin{abstract}
Advancements in molecular biology techniques such as the use of genetic and genome editing methods have resulted in the development of crop plants with improved productivity under the conditions of stressful environments or limited resource availability. However, the first step towards the development of tailored-made crop varieties is the identification of potential candidate genes for manipulation. Once these genes are identified, their expression can be altered either by silencing or activation using these molecular approaches followed by the studies on phenotypic and physiological consequences of the plant related to yield. Protein ubiquitination is a post-translational process which degrades the proteins that are not needed for cellular functions. Owing to the diversity of protein components of Cullin-RING ligases (CRLs), they can be explored for activities, particular stress-regulation, other than their house-keeping functions. In this mini review, we briefly provide a discussion on the genes that encode members of CRLs which are considered to be the potential targets for stress amelioration and enhancement of plant productivity.
\end{abstract}

Keywords: E3-ligase; Cullins; Crop improvement; Genes

\section{Introduction}

Protein ubiquitination is a post-translational mechanism, aims at maintaining protein equilibrium by degrading those proteins that are more than what is required for the normal functioning of the eukaryotic cells. Ubiquitin, a ubiquitously distributed protein (hence the name ubiquitin) ferries the target protein through a cascade of three enzymes; an ubiquitinactivating enzyme (E1), ubiquitin-conjugating (E2) and ubiquitin-Ligase (E3). E3 ligases mainly control the specificity of the ubiquitination process. If the protein ubiquitination fails to regulate the protein turn over, it could result in the development of a disease in animals and lethal or perturbed phenotypes in plants. Thus, an imbalance in protein levels is associated with infections and diseases.

\section{Cullins in developmental and stress regulation}

There are one or two E1 enzymes, dozens of E2s and hundreds of E3 enzymes in eukaryotes and Cullin-RING ligases (CRLs) form the largest E3 family consisting of many subunits [1]. One of the essential components of CRLs is Cullins, present as Cullin 1, Cullin $3 \mathrm{a} / 3 \mathrm{~b}$ and Cullin 4 with each one of them acting as a scaffold to bring the E2 enzymes either directly or via adaptor proteins such as S-Phase kinase-associated protein (SKP) [2]. Cullins are a group of hydrophobic proteins implicated in the scaffolding of Ubiquitin E3-ligases. They are characterized on the basis of their homology domains, which consist of 200 amino acids with a bundle of 4 helical domains, a winged-helix domain followed by $\alpha$ and $\beta$ domains. The size of the Cullin proteins ranges from $85 \mathrm{kDa}$ to $100 \mathrm{kDa}$ [3]. The genome of Saccharomyces cerevisiae encodes three Cullin proteins (Cul1, Cul3, and Cul8) and humans have eight Cullins (Cul1, Cul2, Cul3, Cul4A, Cul4B, Cul5, Cul7 and the closely related p53-associated parkin-like cytoplasmic protein, ParC. The Arabidopsis genome contains five Cullin protein-encoding genes (Cul1, Cul2, Cul3A, Cul4, and ANAPHASE PROMOTING COMPLEX2, APC2 [4]). 
The involvement of Cullins in abiotic stress responses emanated from our study on activation tagging of rice which resulted in the identification of Cullin- 4 as one of the genes responsible for improved water-use efficiency [5]. Based on these findings, we further performed an elaborate study on the biotic and abiotic stress-responsive roles of Cullins and found that some of them became significantly up-regulated, indicating that these genes form important candidates for ameliorating stress tolerance which, however, requires further exploration [6]. The role of Cullins in cell cycle regulation was first identified in nematodes [7]. A Cullin homolog of yeast, cdc53 has been reported for its role in Ubiquitinmediated proteolysis of cell cycle regulators [8]. Arabidopsis Cul1 mutants exhibited embryonic lethality [9], whereas a point mutation in AtCul1 has revealed its role in jasmonate response [10]. Similarly, AtCul3a and AtCul3b proteins in Arabidopsis bind to RBX1 with their C-terminal region and these Cul3 based CRLs are essential for embryo development [11].

\section{Other components of E3-ligases}

The necrotrophic pathogen infection or pest attack initiates a jasmonic acid pathway to pursue the defense response in plants. Arabidopsis COI1 (Coronatine-insensitive 1) is an F-box protein that regulates jasmonic acid-dependent defense pathways. COI1 negatively regulates the repressor of JA transduction [12]. Jasmonate Zim domain (JAZ), a repressor of jasmonic acid signaling is the target of Skp1/Cullin/F-boxCOI1 (SCF) E3 ligase protein degradation complex [13]. After infection, the increase in the level of JA enhances the interaction of JAZ repressor with SCF-COI complex, which leads to transcriptional activation of JA-responsive genes. Rice coi1 mutants were found to be highly susceptible to the pathogen infection and insect attack. A similar mutation in JAZ protein increased the herbivore susceptibility $[14,15]$.

Protein ubiquitination pathway has also been a major target to develop metal tolerant plants [16]. Rice transgenic plants overexpressing OsHIR1, encoding an E3 ligase, exhibited tolerance to toxic levels of heavy metals [17]. AtHOS1 protein encodes an E3 ligase that mediates the degradation of a master 97 regulatory protein, ICE1 (Inducer of CBF Expression), thus associates the role of E3 ligases in response to extreme temperatures as well [18]. Overexpression of genes involved in protein ubiquitination does not always enhance tolerance. For example, silencing of OsDSG1 encoding an E3 ligase resulted in drought and salttolerant transgenic rice plants, indicating that some of the genes of this complex act as negative regulators also. Although many reports have shown the overexpression or silencing of E3 ligase components resulting in enhanced tolerance to abiotic stresses, the stress regulatory roles of Cullins have not been elaborated in great detail. The stress-regulatory role of Cullins can be exploited further by the functional characterization of the selected stress-responsive Cullin genes through genetic or genome engineering methods, which might help in augmenting productivity of crop plants under stressful environments.

\section{Acknowledgement}

MM acknowledges the grants received from the Department of Science and Technology, Government of India, in the form of DSTINSPIRE Faculty award.

\section{References}

1. Albert L (2015) Gestión de los productos químicos. En: México Tóxico. Albert LA, Jacott M (Eds.), 1a. XXI Siglo veintiuno editors Edn, México. 21-37.

2. Zaidi J, Pal A (2017) Review on heavy metal pollution in major lakes of India: Remediation through plants. Afr J Environ Sci Technol 11(6): 255265.

3. Mena MI, Bustamante GA, Vargas LS, Olvera HJI, Méndez EJA (2017) Evaluación de la condición ecológica del río Zahuapan. Rev Int Contam Ambie 33(1): 7-19.

4. Covarrubias SA, Peña Cabriales JJ (2017) Contaminación ambiental por metales pesados en México: Problemática y estrategias de fitorremediación. Rev Int Contam Ambie 33: 7-21.

5. Cortés JEV, Mugica ÁV, González CMC, Carrillo GR, Martínez GM, et al. (2013) Natural revegetation of alkaline tailing heaps at Taxco, Guerrero, Mexico. Int J Phytoremediation 15(2): 127-141.

6. Ortíz OE, García NE, Juárez SL, Gómez CMA, García GE, et al. (2017) Lead exposure: pottery impact in Tlaxcala, México. Rev Int Contam Ambie 33(1): 57-64.

7. Ramos AYR, Siebe GCD (2006) Estrategia para identificar jales con potencial de riesgo ambiental en un distrito minero: estudio de caso en el Distrito de Guanajuato, México. Rev Mex Cienc Geol 23(1): 54-74.

8. SEMARNAT (2007) Norma Oficial Mexicana. NOM-147-SEMARNAT/ SSA1-2004. Que establece los criterios para determinar las concentraciones de remediación de suelos contaminados por arsénico, bario, berilio, cadmio, cromo hexavalente, mercurio, níquel, plata, plomo, selenio, talio y/o vanadio. Secretaría de Medio Ambiente, Recursos Naturales y Pesca. Diario Oficial de la Federación.

9. SEMARNAT (2003) Norma Oficial Mexicana NOM-001-SEMARNAT 1996. Que establece los límites máximos permisibles de contaminantes en las descargas de aguas residuales en aguas y bienes nacionales. Secretaría de Medio Ambiente, Recursos Naturales y Pesca. Diario Oficial de la Federación.

10. Nava RC, Méndez AM (2011) Efectos neurotóxicos de metales pesados (cadmio, plomo, arsénico y talio). Arch Neurocienc Mex 16(3): 140-147.

11. Fawzy EM, Abdel Motaal FF, El Zayat SA (2017) Biosorption of heavy metals onto different eco-friendly substrates. J Bioremediat Biodegrad 8(3): 1-7.

12. Yang S, Sun X, Shen Y, Chang Ch, Guo E, et al. (2017) Tolerance and removal mechanisms of heavy metals by the fungus Pleurotus ostreatus HAAS. Water Air Soil Pollut 228(130): 1-9.

13. Rivas CAM, Guatemala CME, Rojas ANG (2017) Effect of aluminum in Bacillus megaterium nickel resistance and removal capability. Mex J Biotechnol 2(2): 206-220.

14. Grujić S, Vasić S, Radojević I, Čomić L, Ostojić A (2017) Comparison of the Rhodotorula mucilaginosa biofilm and planktonic culture on heavy metal susceptibility and removal potential. Water Air Soil Pollut 228(73): 1-8.

15. Jin Y, Yu S, Teng Ch, Song T, Dong L, et al. (2017) Biosorption characteristic of Alcaligenes sp. BAPb.1 for removal of lead (II) from aqueous solution. 3 Biotech 7(2): 123.

16. Moctezuma ZMG, Robles GA, Cárdenas GJF, Rodríguez PAS, Navarro CJF et al. (2017) Isolation and identification of fungi and yeast resistant to Lead (II). J Multidiscip Eng Sci Technol 4(6): 5273-5278. 
17. Acosta I, Rodríguez X, Gutiérrez C, Moctezuma MG (2004) Biosorption of chromium (VI) from aqueous solutions by fungal biomass. Bioinorg Chem Appl pp. 1-7.

18. Mukhopadhyay M, Noronha SB, Suraishkumar GK (2011) A review on experimental studies of biosorption of heavy metals by Aspergillus niger. Can J Chem Eng 89(4): 889-900.

19. Kapoor A, Viraraghavan T, Cullimore DR (1999) Removal of heavy metals using the fungus Aspergillus niger. Bioresource Technol 70(1): 95-104.

20. Yanga J, Wang Q, Luoa Q Wang Q Wud T (2009) Biosorption behavior of heavy metals in bioleaching process of MSWI fly ash by Aspergillus niger. Biochem Eng J 46(3): 294-299.

21. Tsekova K, Todorova D, Ganeva S (2010) Removal of heavy metals from industrial wastewater by free and immobilized cells of Aspergillus niger. Int Biodeterior Biodegradation 64(6): 447-451.

22. Pokhrel D, Viraraghavan $\mathrm{T}$ (2006) Arsenic removal from an aqueous solution by a modified fungal biomass. Water Res 40(3): 549-552.

23. Greenberg AE, Clesceri LS, Eaton AD (1992) Standard methods for the examination of water and wastewater, $18^{\text {th }}$ edn. American Public Health Association, Washington, DC, USA, pp. 1-49.

24. Charlot G (1964) Colorimetric determination of elements. (trad. da $12^{\text {th }}$ edn. francesa) Elsevier Publishing Company-Amsterdam, Netherlands, p. 449.

25. SEDECO (2015) Directorio de empresas que operan en las zonas y parques industriales de la ciudad de San Luis Potosí. Secretaría de Desarrollo Económico. San Luis Potosí, México.

26. Valix M, Loon LO (2003) Adaptive tolerance behaviour of fungi in heavy metals. Mineral Eng 16(3): 193-198.

27. Rehman A, Anjum MS (2011) Multiple metal tolerance and biosorption of cadmium by Candida tropicalis isolated from industrial effluents: glutathione as detoxifying agent. Environ Monit Assess 174(1-4): 585595.

28. Liu YG, Fan T, Zeng GM, Li X, Tong Q, et al. (2006) Removal of Cadmium and Zinc Ions from aqueous solution by living Aspergillus niger. Transactions of Nonferrous Metals Society of China 16(3): 681686.

29. Akhtar MN, Sastry KS, Mohan PM (1996) Mechanism of metal ion biosorption by fungal biomass. Biometals 9(1): 21-28.

30. Rojas ANG, Otamendi VJ, Gómez RM (2017) Metal leaching from a spent catalyst by Alternaria alternata. Mex J Biotechnol 2(2): 221-231.

31. Santos DEE, Cárdenas JF, Torre ME, Martínez VM, Rodríguez A, et al. (2017) Bioadsorción de Arsénico (III) en solución acuosa por la Biomasa Modificada de Aspergillus niger. Avan en Cienc e Ing 8(2). 1-10.

32. Cárdenas GJF, Acosta RI, Terán FY, Rodríguez PAS (2017) Bioremoval of arsenic (V) from aqueous solutions by chemically modified biomass. 3 Biotech 7 (3): (226).

33. Salvadori MR, Ando RA, Oller do Nascimento CA, Correa B (2014) Intracellular biosynthesis and removal of copper nanoparticles by dead biomass of yeast isolated from the wastewater of a mine in the Brazilian Amazonia. PLoS One 9(1): e87968.
34. Leyva RR (2010) Fundamentos de adsorción en sistemas liquido-sólido. Situacion del arsenico en la Region Iberica e Iberoamericana. Posibles acciones articuladas e integradas para el abatimiento del arsenico en zonas aisladas. CYTED, Argentina Chapter 3, p. 43.

35. Kratochvil D, Volesky B (1998) Advances in the biosorption of heavy metals. Trends in Biotechnology 16(7): 291-300.

36. Swelam AA, Awad MB, Salem AMA, El Feky AS (2017) Biosorption of Cobalt (II) Ions from aqueous solution using rice straw and its modification. J Sci Eng Res 4(1): 121-129.

37. Sánchez DRG, Martínez MMR, Correa MMA, Saldival CJ, Sánchez MDI, et al. (2017) Síntesis de hidrogeles de quitosano a partir de cáscara de camarón para ensayos de bioadsorción de cobre. Rev Int Contam Ambien 33: 93-98.

38. Kumar R, Bishnoi N, Garima R, Bishnoi K (2008) Biosorption of chromium (VI) from aqueous solution and electroplating wastewater using fungal biomass. Chem Eng J 135(3): 202-208.

39. Li CH, Yu J, Wang D, Li L, Yang X, et al. (2016) Efficient removal of zinc by multi-stress-tolerant yeast Pichia kudriavzevii A16. Bioresour Technol 206: 43-49.

40. Nguyen ML, Ruey Shin J (2015) Modification of cross linked chitosan beads with histidine and Saccharomyces cerevisiae for enhanced Ni (II) biosorption. J Taiwan Inst Chem Eng 56: 96-102.

41. Ruta L, Paraschivescu C, Matache M, Avramescu S, Farcasanu IC (2010) Removing heavy metals from synthetic effluents using "kamikaze" Saccharomyces cerevisiae cells. Appl Microbiol Biotechnol 85(3): 763771.

42. Tobin M J, Cooper DG, Neufeld RJ (1988) The effects of cation competition on metal adsorption by Rhizopus arrhizus biomass. Biotechnol Bioeng 31: 282-286.

43. Vadkertiova R, Slavikova E (2006) Metal tolerance of yeasts isolated from water, soil and plant environments. J Basic Microbiol 46(2): 145152 .

44. Ali A, Di G, Mahar A, Ping W, Feng S, Ronghua L, et al. (2017) Mycoremediation of potentially toxic trace elements. a biological tool for soil cleanup: A review. Pedosphere 27(2): 205-222.

45. Beltrán M, Gómez A (2015) Metales pesados (Cd, Cr y Hg) Su impacto en el ambiente y posibles estrategias biotecnológicas para su remediación. Rev 2(2): 82-112.

46. Covarrubias SA, García BJA, Peña CJJ (2015) El papel de los microorganismos en la biorremediación de suelos contaminados con metales pesados. Acta Universitaria 25(3): 40-45.

47. Sala LF, García SI, González JC, Frascaroli MI, Bellú S, et al. (2010) Biosorción para la eliminación de metales pesados en aguas de desecho. Real Sociedad Española Química 106(2): 114-120.

48. Rodríguez IA, Cárdenas González JF, Moctezuma Zárate MG, Rodríguez PA, Martínez Juárez VM (2017) Hexavalent Chromium (VI) Removal by Aspergillus niger. In: "Metal-microbe interactions and bioremediation: Principles and applications for toxic metals". Surajis Das (Ed). CRS Press Book. Taylor\&Francis. Chapter 42, pp. 673-688. 